\title{
Pseudoscillatoria coralii gen. nov., sp. nov., a cyanobacterium associated with coral black band disease (BBD)
}

\author{
Diana Rasoulouniriana1, Nachshon Siboni ${ }^{2}$, Eitan Ben-Dov ${ }^{2,3}$, \\ Esti Kramarsky-Winter ${ }^{4}$, Yossi Loya ${ }^{4}$, Ariel Kushmaro ${ }^{2,5, *}$ \\ ${ }^{1}$ Unit of Environmental Engineering and ${ }^{2}$ Department of Biotechnology Engineering, Faculty of Engineering Sciences, \\ Ben-Gurion University of the Negev, PO Box 653, Be'er-Sheva 84105, Israel \\ ${ }^{3}$ Achva Academic College, MP Shikmim 79800, Israel \\ ${ }^{4}$ Department of Zoology, Tel-Aviv University, Tel-Aviv 69978, Israel \\ ${ }^{5}$ National Institute for Biotechnology of the Negev, Ben-Gurion University of the Negev, PO Box 653, Be'er-Sheva 84105, \\ Israel
}

\begin{abstract}
Black band disease (BBD) is a widespread coral disease which mainly infects massive framework-building corals. BBD is believed to be caused by a consortium of microorganisms and may not result from the actions of a primary pathogen. The BBD microbial community is dominated, in terms of biomass, by filamentous cyanobacteria. Here we describe a cyanobacterial strain, designated BgP10_4S ${ }^{\mathrm{T}}$, cultured from a BBD-affected Favia sp. coral from the northern Red Sea (Gulf of Eilat, Israel). This dark-green pigmented cyanobacterium showed optimal growth at salinities of 5.0 to $5.5 \%(\mathrm{w} / \mathrm{v}), \mathrm{pH}$ of 7 to 8 and cultivation temperatures of $25^{\circ} \mathrm{C}$. Morphological examination revealed cylindrical, unbranched trichomes with tapering and blunt cells at the ends which leave a thin mucilaginous trail as they glide. No sheath was evident under these conditions. Inclusion bodies and straight thylakoids were clearly discerned by transmission electron microscopy. Pigment analysis revealed absorption spectra for phycocyanin, carotenoid and chlorophyll $a$. The sequence of the 16S rRNA gene in this cyanobacterium isolate showed high similarity $(99 \%)$ to cyanobacterial sequences retrieved from BBD-affected corals from different geographical sites (i.e. the Caribbean Sea, Palau and the Red Sea). The BgP10_4S $\mathrm{S}^{\mathrm{T}}$ strain is observed to be a persistent component of the BBD mat of Faviid corals and may thus be an important agent in the disease etiology. On the basis of its morphological, physiological and phylogenetic distinctiveness, strain BgP10_4S ${ }^{\mathrm{T}}$ represents a novel genus and species of Subsection III (formerly Oscillatoriales), for which the name Pseudoscillatoria coralii gen. nov., sp. nov. is proposed.
\end{abstract}

KEY WORDS: Black band disease $\cdot$ Marine cyanobacteria $\cdot$ Oscillatoriales $\cdot$ Pseudoscillatoria coralii . Stony corals Resale or republication not permitted without written consent of the publisher

\section{INTRODUCTION}

Black band disease (BBD) is a widespread coral malady infecting massive framework-building corals (Frias-Lopez et al. 2004). The disease is globally distributed and has been described on reefs throughout the Caribbean (Weil 2004), in the Indo-Pacific and Red Sea (Antonius 1985, Al-Moghrabi 2001, Barneah et al.
2007, Zvuloni et al. 2009) and in the Great Barrier Reef (Willis et al. 2004). BBD is believed to be caused by a consortium of microorganisms (Antonius 1981, Richardson 1998, Dinsdale 2002) and may not have a primary pathogen (Richardson 2004). It was found that the BBD-associated microbial community is dominated, in terms of biomass, by filamentous gliding cyanobacteria (Rützler \& Santavy 1983, Bythell et al. 
2002, Cooney et al. 2002, Frias-Lopez et al. 2003, Richardson 2004). The progression of the disease is characterized by a black band or mat of microorganisms dominated by cyanobacteria that migrate across the coral colony (Rützler \& Santavy 1983, Taylor 1983, Barneah et al. 2007). Indeed, most of the cyanobacterial sequences retrieved from BBD-affected corals from different geographic regions showed relationships to the genera Geitlerinema, Leptolyngbya and Oscillatoria of the order Oscillatoriales (Rützler \& Santavy 1983, Frias-Lopez et al. 2003, Sekar et al. 2006, Sussman et al. 2006, Barneah et al. 2007, Myers et al. 2007, Richardson et al. 2007, Richardson \& Ragoonath 2008).

Oscillatoriales are known in the marine environment, with many being pathogenic to marine invertebrates and vertebrates through the production of toxins (Smith 1996, Mez et al. 1997, Carmichael \& Li 2006). Moreover, strains of this order are known to form marine cyanobacterial mats (Antonius 1981). In the present study we describe the taxonomic properties of a cyanobacterium strain BgP10_4 $\mathrm{S}^{\mathrm{T}}$ that originated from BBD-affected Favia sp. from the northern Red Sea (Gulf of Eilat, Israel). Here we describe phenotypic, genotypic and phylogenetic characteristics of this strain.

\section{MATHERIALS AND METHODS}

Sample collection and culturing. Using $10 \mathrm{ml}$ syringes, samples of the black band were collected from the surface of the coral Favia sp. (at depths ranging from 1 to $5 \mathrm{~m}$ ) from a site opposite the Interuniversity Institute for Marine Science, Eilat, Israel (IUI, $29^{\circ} 51^{\prime} \mathrm{N}, 34^{\circ} 94^{\prime}$ E). Samples were brought to the surface and immediately processed. For isolation of the BgP10_4S ${ }^{\mathrm{T}}$ cyanobacterial strain, initial liquid samples were plated on BG11 Fluka (Buchs) agar plates and incubated at $22^{\circ} \mathrm{C}$ (typical late spring-early summer seawater temperatures, a period when the disease is first observed in the shallow water of the Gulf of Eilat) under a $12 \mathrm{~h}$ light:12 h dark cycle. The BG11 medium was prepared using artificial seawater (Instant Ocean) in order to maintain the BgP10_4 $\mathrm{S}^{\mathrm{T}}$ culture at the desired salinity $(4 \% \mathrm{w} / \mathrm{v})$. From this culture, single cyanobacterial filaments were transferred to a liquid BG11 medium, grown and then plated again on BG11 plates, thus producing monocyanobacterial cultures of this strain. To ascertain temperature optima for growth, BgP10_4S $\mathrm{S}^{\mathrm{T}}$ biomass were plated on BG11 agar and incubated at 22,25 and $30^{\circ} \mathrm{C}$. After 2 wk of incubation, the expansion zones of the colonies were measured with a ruler on the undersurface of the Petri dish. The salinity range for growth of the cyanobacteria was determined using a sea salt mixture (Instant Ocean) for preparing artificial seawater at concentrations of 3.5 to $6.5 \%(\mathrm{w} / \mathrm{v}$ at intervals of $0.5 \%$ ) and 8 to $12 \%$ (w/v at intervals of $1 \%$ ). The $\mathrm{pH}$ of a BG11 liquid culture medium (with $4 \% \mathrm{w} / \mathrm{v}$ sea salt) was adjusted by adding alkaline $(\mathrm{NaOH})$ or acid (Tris-citrate buffer) compounds to produce $\mathrm{pH}$ of 4.5, 5, 7, 9, 10 and 11. Optimal $\mathrm{pH}$ was assessed by the qualitative appearance of BgP10_4S $\mathrm{S}^{\mathrm{T}}$ biomass which attached and coated walls of the Erlenmeyer flasks.

DNA extraction and PCR amplification. For molecular identification, genomic DNA was extracted from the cyanobacterial cultures (Wilson 1987) using a PowerSoil DNA Isolation kit (Mo Bio Laboratories) according to the manufacturer's instructions. Genomic DNA was eluted using $40 \mu \mathrm{l}$ of elution buffer or double distilled water and stored at $-20^{\circ} \mathrm{C}$. Total DNA was amplified by PCR with a Mastercycler gradient thermocycler (Eppendorf) using the specific 16S rRNA gene cyanobacterial primers, 106F (CGG ACG GGT GAG TAA CGC GTG A) and 781R (GAC TAC TGG GTA TCT AAT CCC ATT) (Nübel et al. 1997, Sussman et al. 2006).

Phylogenetic analysis. Amplified 16S rRNA gene sequences were compared with those in the GenBank database with the basic local alignment search tool (BLAST) network service (www.ncbi.nlm.nih.gov/ blast/blast.cgi) and aligned with representative species from the order Oscillatoriales using CLUSTALW, part of the MEGA package (Kumar et al. 2004). A phylogenetic tree was constructed by the neighborjoining method (Saitou \& Nei 1987) using the MEGA package (Kumar et al. 2004). Bootstrap resampling analysis (Felsenstein 1985) for 100 replicates was performed to estimate the confidence levels of tree topologies.

Nucleotide sequence accession number. The $16 \mathrm{~S}$ rRNA gene sequence was deposited in GenBank and given accession number FJ210722.

Pigment analysis. Chlorophyll extraction was carried out using methanol, followed by heating for $2 \mathrm{~min}$ at $70^{\circ} \mathrm{C}$. The extract was centrifuged and the clear supernatant solution was used for measurement (Talling 1969). Water-soluble phycobilin pigment extraction was carried out by overnight freezing of the cell suspension. After thawing and vortex-mixing, each sample was centrifuged to obtain an aqueous supernatant (Francis 2001). Absorption spectra of the cyanobacteria samples were examined using a UV/visible spectrometer (Agilent 8453, Agilent Technologies).

Cell structure identification. For ultrastructural characterization, cells of strain BgP10_4 $\mathrm{S}^{\mathrm{T}}$ cultivated in BG11 liquid media were fixed with $2.5 \%$ gluteraldehyde in phosphate-buffered saline (simulating seawater osmolarity) overnight, then washed, post-stained with osmium tetraoxide, serially dehydrated in ethanol 
(30, 50, 70 and 100\%), embedded in Araldite epoxy resin (Electron Microscopy Sciences) and sectioned in 70 to $80 \mathrm{~nm}$ slices (Hoppert \& Holzenburg 1998). The resulting sections were stained with uranyl acetate and lead citrate, and examined using a JEM-1230 transmission electron microscope at an excitation voltage of $80 \mathrm{kV}$ (Harel et al. 2008).

Fatty acid content. Fatty acid content was analyzed by GC-MS using a protocol adjusted for cyanobacteria (Caudales et al. 2000). The composition of the fatty acid content of the cells was described by co-chromatography with reference standards (MIST02).

\section{RESULTS}

A monoalgaic culture of strain BgP10_4 $\mathrm{S}^{\mathrm{T}}$ originating from BBD-affected Favia sp. coral was obtained. Strain BgP10_4 $\mathrm{S}^{\mathrm{T}}$ is a gram-negative gliding filamentous cyanobacterium 5 to $6 \mu \mathrm{m}$ in width (Fig. 1), with phenotypic characterizations listed in Table 1 . The strain is a slow grower in liquid culture, forms a dark-green coat on the walls of the Erlenmeyer flasks and a bead-like coat on agar plates. No growth was evident when the cultures were maintained in the dark. On BG11 agar plates, trichomes were detected only 2 wk after plating, therefore making it difficult to determine generation time. No heterocysts were evident in this strain when examined under both light microscopy and transmission electron microscopy. Morphological examination revealed cylindrical unbranched trichomes with tapering and blunt cells at the ends (Fig. 1). Trichomes were found to leave a thin mucilaginous trail as they glide, although no sheath of mucilage was noted (Fig. 2a). Several pigments were identified spectrophotometrically, namely water-soluble phycocyanin, with an ab-
Table 1. Differential characteristics of strain BgP10_4S ${ }^{\mathrm{T}}$. Lipid content does not include trace amounts and compounds showing similarity to library compounds lower than $90 \%$. Yes: positive; no: negative

\begin{tabular}{|ll|}
\hline Characteristic & Strain BgP10_4S $\mathrm{S}^{\mathrm{T}}$ \\
\hline Morphology & Filamentous \\
Trichome width & $5-6 \mu \mathrm{m}$ \\
Hetrocyst formation & No \\
Motility & Yes \\
Color of cultures & Dark green \\
Pigments & Chlorophyll $a$, \\
& phycocyanin, carotenoid \\
Photosynthetic activity & Yes \\
Optimal salinity & $5-5.5 \%$ (w/v) \\
Optimal pH & $7-8$ \\
Optimal temperature & $25^{\circ} \mathrm{C}$ \\
Aerobic growth in the dark & No \\
Lipid content & \\
16:0 & $58.61 \%$ \\
$16: 1$ & $6.39 \%$ \\
$16: 3$ & $14.08 \%$ \\
$17: 1$ & $6.99 \%$ \\
$18: 1$ & $7.13 \%$ \\
$18: 2$ & $6.80 \%$ \\
\hline
\end{tabular}

sorption maximum at $623 \mathrm{~nm}$, chlorophyll $a$, with 2 absorption peaks at 436 and $666 \mathrm{~nm}$, and carotenoid, with an absorption maximum at $336 \mathrm{~nm}$. The detection of chlorophyll and the fact that when exposed to light this organism grows on BG11, a medium that is almost free of organic nutrients, suggests that the strain comprises photoautotrophic bacteria.

The optimal growth temperature for BgP10_4S $\mathrm{S}^{\mathrm{T}}$ was $25^{\circ} \mathrm{C}$. At this temperature, the $\mathrm{pH}$ range for growth was between 5 and 11, with optimal growth occurring between $\mathrm{pH} 7$ and 8. Optimal growth was observed from 5 to $5.5 \%(\mathrm{w} / \mathrm{v})$ salinity, while there was no

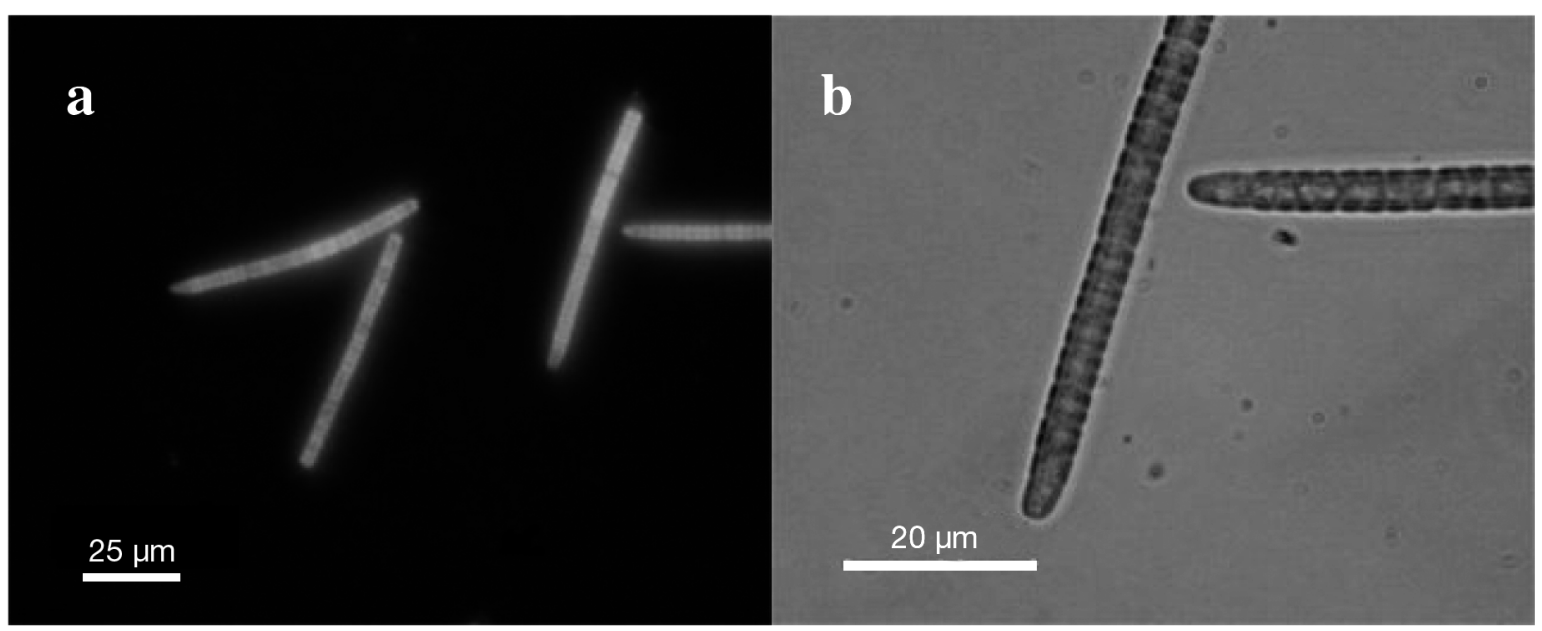

Fig. 1. Photomicrographs of Pseudoscillatoria coralii strain BgP10_4S $\mathrm{S}^{\mathrm{T}}$ under (a) UV and (b) phase contrast conditions. Images were taken at $400 \times$ and $1000 \times$ magnification, respectively 


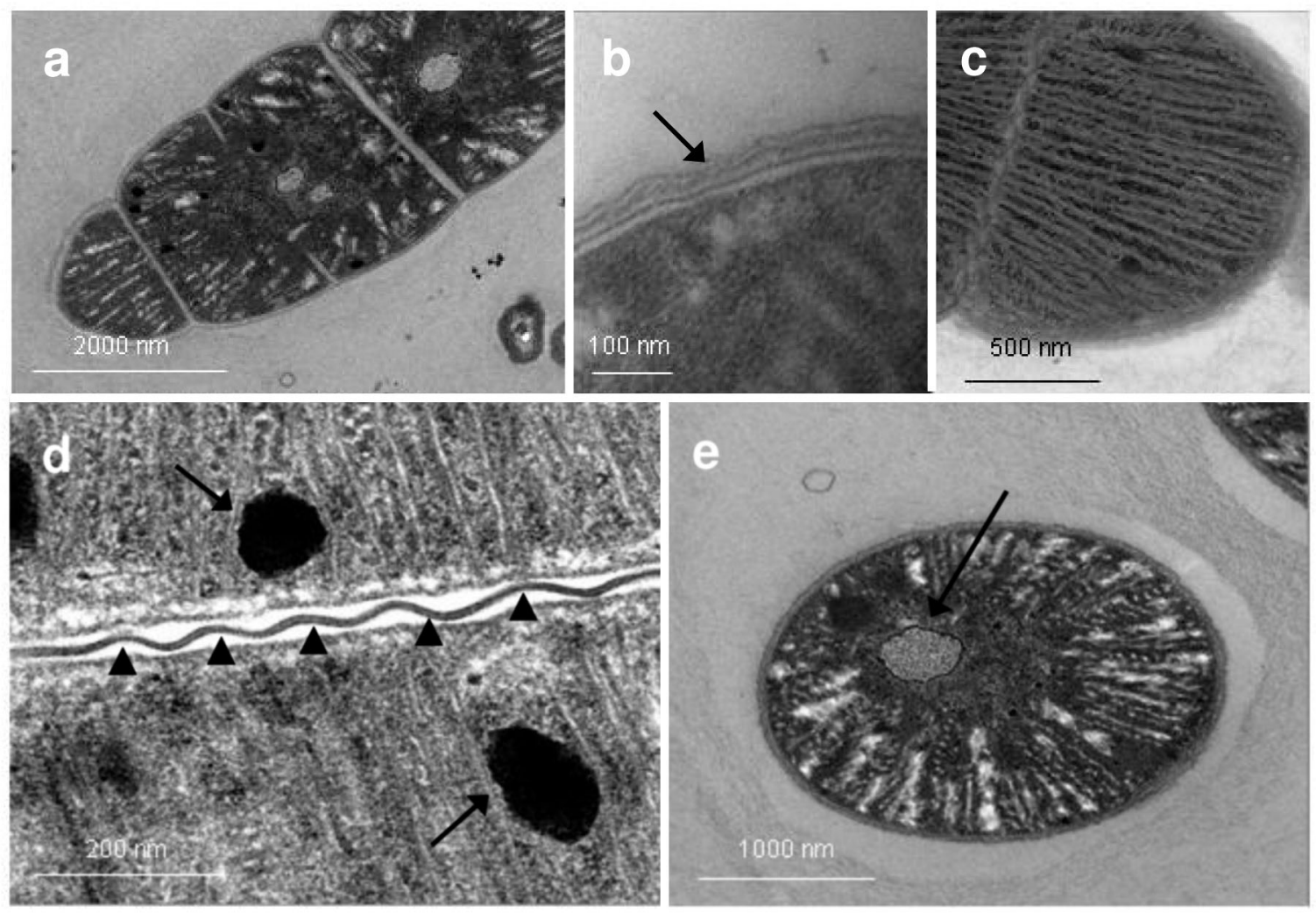

Fig. 2. Transmission electron micrographs of Pseudoscillatoria coralii strain BgP10_4S ${ }^{\mathrm{T}}$. (a) Apical oriented trichome; (b) enlargement of the cell wall, demonstrating the typical gram-negative layered structure (arrow); (c) thylakoids (note the parallel arrangement as seen in long-section); (d) undulating septa between cells (arrowheads) and black inclusion bodies within the cells (arrows); and (e) cross-section of trichome, revealing light inclusion bodies (arrow)

growth observed below $4 \%$ (w/v). The major cellular straight, long-chain fatty acid (>50\%) was C16:0. In addition, 16:1, 16:3, 17:1, 18:1 and 18:2 fatty acids were present (Table 1), with ratios of mono- to polyunsaturated fatty acids of nearly 1:1.

Microscopic observation showed single trichomes with tapered and blunt ends (Figs. 1 \& 2a) that displayed fluorescence when excited under UV light. Several identifying morphological features were detected. These include a multilayered cell wall (Fig. 2b) consisting of a number of membrane structures divided by electron opaque layers containing darkly stained inclusion bodies. In addition, separate parallel thylakoids; these appear parallel in long-section (Fig. 2c), but radial in distribution in crosssection, were evident (Fig. 2e), as were undulating partitions between the trichomes (Fig. 2d). Various inclusions, such as dark (Fig. 2d) and white bodies (Fig. 2e), were also visible. Strain BgP10_4S ${ }^{\mathrm{T}}$ (SAG NA 2008.006; temporary number) is under deposition at the Culture Collection of Algae (SAG) at Georg August University, Göttingen, Germany. The 16S rRNA gene sequence of BgP10_4S $\mathrm{S}^{\mathrm{T}}$ (accession no. FJ210722) was found to have $91 \%$ similarity to a previously isolated cyanobacterium from a marine sponge, Oscillatoria spongeliae (AY615503; Fig 3).

\section{DISCUSSION}

Cyanobacteria strain BgP10_4 $\mathrm{S}^{\mathrm{T}}$ isolated and cultured from a BBD-affected colony of the coral Favia sp. from the northern Red Sea (Gulf of Eilat) are gramnegative, gliding filamentous non-heterocystous, photoautotrophic cyanobacteria containing parallel thylakoids and various inclusion bodies (Figs. 1 \& 2). Filament pigments include phycocyanin, carotenoid and chlorophyll a. The cells contain long-chain fatty acids of a straight-chain saturated nature, over $50 \%$ of which are C16:0. In our cyanobacterial specimens, multilayered cell walls, consisting of a number of membrane structures divided by electron opaque layers, were evident (Fig. 2b). In addition, the filaments contained darkly stained inclusion bodies, and separate parallel thylakoids were observed (Fig. 2a,c-e). Moreover, the cylindrical, unbranched trichomes with conical and blunt apical cells (Figs. 1 \& 2a) morphologically define the cultured cyanobacteria strain 


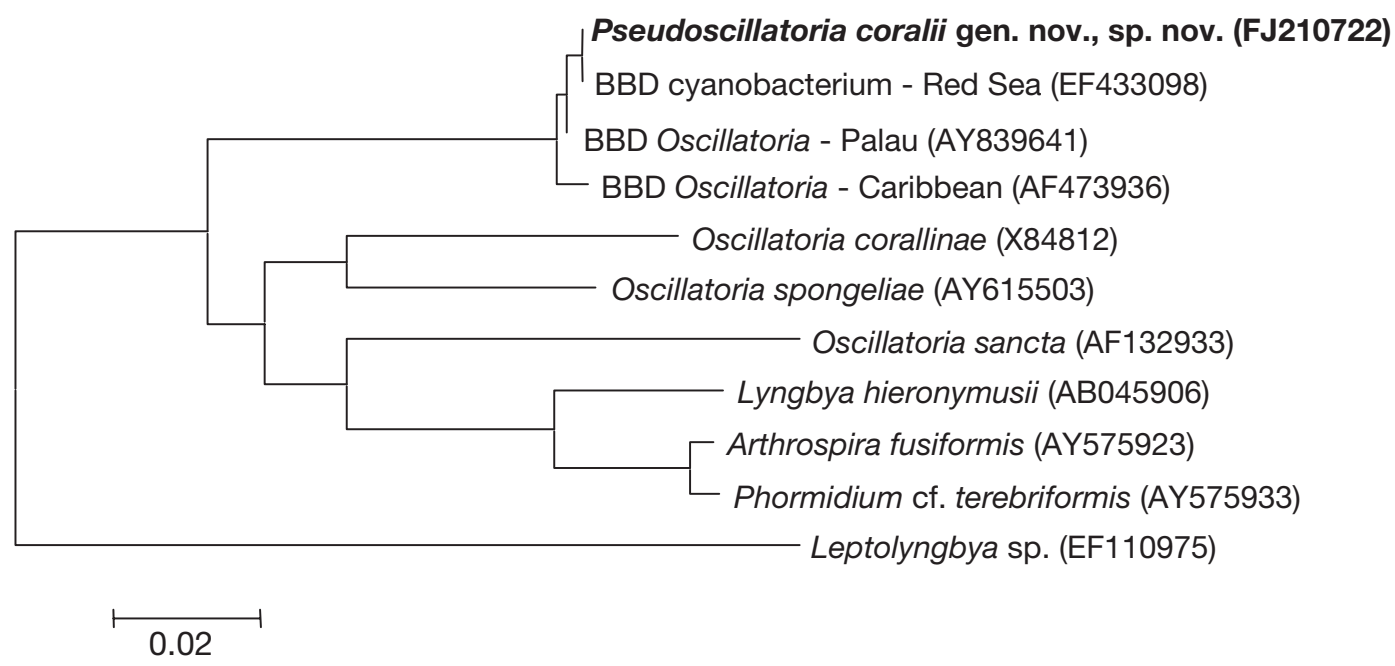

Fig. 3. Neighbor-joining 16S rRNA gene phylogenetic tree showing the relationship between strain BgP10_4S ${ }^{\mathrm{T}}$ (Pseudoscillatoria coralii gen. nov., sp. nov.) in bold type and representative species of Subsection III. Sequence accession nos. are given. The scale bar represents 2 substitutions per 100 nucleotide positions

BgP10_4 $\mathrm{S}^{\mathrm{T}}$ as belonging to Subsection III (Oscillatoriales in the traditional sense), which includes almost all filamentous cyanobacteria with uniplanar binary fission with no heterocyst (Castenholz et al. 2001). According to Castenholz et al. (2001), the genus Oscillatoria is widely distributed in fresh, marine and brackish waters. Some species seem almost black, and can synthesize chlorophyll, phycoerythrin and phycocyanin without chromatic adaptation. Some are known as the motile components of microbial mats. Oscillatoria species divide exclusively by binary fission in one plane and are further characterized by cylindrical straight trichomes and, in some cases, cap-like thick terminal cells. Sheaths of this genus may be nearly invisible; however, although trichomes of the strain BgP10_4 $\mathrm{S}^{\mathrm{T}}$ were found to leave a thin mucilaginous trail as they glide, no sheath of mucilage was present. Members of the closely related genus Oscillatoria are well known for their motility, with their trichomes gliding by means of undulation of their microfibrils while the cells maintain contact with a solid substrate. Mucilage is secreted through pores in the cell wall and may help to provide better contact with the substrate surface (Van den Hoek et al. 1995).

The optimal growth of $\mathrm{BgP} 10 \_4 \mathrm{~S}^{\mathrm{T}}$ (originating from BBD-affected Favia sp.) was obtained at $\mathrm{pH} 7$ to 8 , $25^{\circ} \mathrm{C}$, in 5 to $5.5 \%$ (w/v) salinity; low or no growth was evident at lower salinities $(<4 \% \mathrm{w} / \mathrm{v})$. In the northern Gulf of Eilat in the summer months during the active spread of the disease, the water temperature at 1 to $3 \mathrm{~m}$ depth where the disease is most prevalent (Barneah et al. 2007) is approximately $26^{\circ} \mathrm{C}$, salinity is $4 \%(\mathrm{w} / \mathrm{v})$ and $\mathrm{pH}$ is around 8 . Hence, these conditions are sufficient for reproduction of the strain on coral surface. In general, BBD cyanobacteria contend with harsh surroundings existing in BBD mats. Recently, Richardson \& Ragoonath (2008) demonstrated the ability of the BBD cyanobacterium Geitlerinema (AF474001) to use exogenous organic carbon to enhance survival in the dark under the anaerobic (as well as illuminated aerobic), sulfide-rich conditions existing in BBD mats.

Recent cyanobacterial 16S rRNA gene sequences retrieved from BBD-affected corals distributed globally were identified as belonging to the genera Geitlerinema, Leptolyngbya and Oscillatoria of Subsection III (Sekar et al. 2006, Sussman et al. 2006, Barneah et al. 2007, Myers et al. 2007, Richardson et al. 2007, Richardson \& Ragoonath 2008). Molecular identification of the 16S rRNA gene sequence of BgP10_4 $\mathrm{S}^{\mathrm{T}}$ (1432 bases; FJ210722) displayed a 99\% similarity to the cyanobacteria (i.e. AF473936, AY839641 and EF433098) retrieved from BBD species collected at different sites, such as the Caribbean Sea, Palau and the Red Sea, respectively (Cooney et al. 2002, Sussman et al. 2006, Barneah et al. 2007). Moreover, the BgP10_4S $\mathrm{S}^{\mathrm{T}}$ sequence showed a $91 \%$ similarity to the closest cultured cyanobacterial relative, Oscillatoria spongeliae (AY615503), previously isolated from a marine sponge (Fig. 3). These findings suggest that strain BgP10_4 $\mathrm{S}^{\mathrm{T}}$ is a ubiquitous member of the BBD community and may be an important agent in the disease etiology. Hence, based on its morphological properties, growth characteristics, fatty acid composition and phylogenetic distinctiveness, we propose that strain BgP10_4 $\mathrm{S}^{\mathrm{T}}$ be classified as a novel genus and species in Subsection III, for which the name Pseudoscillatoria coralii gen. nov., sp. nov. is proposed. 
Acknowledgements. This work was supported by ISF Grant no. 1169/7. We thank Y. Lichtenfeld and R. Yager from BenGurion University for their assistance with electron microscopy and N. Paz from Tel Aviv University for editing the manuscript. We also thank the Interuniversity Institute for use of their facilities.

\section{LITERATURE CITED}

Al-Moghrabi SM (2001) Unusual black band disease (BBD) outbreak in the northern tip of the Gulf of Aqaba (Jordan). Coral Reefs 19:330-331

Antonius A (1981) Coral reef pathology: a review. Proc 4th Int Coral Reef Symp 2:3-6

Antonius A (1985) Coral diseases in the Indo-Pacific: a first record. PSZN I: Mar Ecol 6:197-218

Barneah O, Ben-Dov E, Kramarsky-Winter E, Kushmaro A (2007) Characterization of black band disease in Red Sea stony corals. Environ Microbiol 9:1995-2006

Bythell JC, Barer MR, Cooney RP, Guest JR, O'Donnell AG, Pantos O, Le Tissier MDA (2002) Histopathological methods for the investigation of microbial communities associated with disease lesions in reef corals. Lett Appl Microbiol 34:359-364

Carmichael WW, Li RH (2006) Cyanobacteria toxins in the Salton Sea. Saline Syst 2:5

Castenholz RW, Rippka R, Herdman M, Wilmotte A (2001) Subsection III (formerly Oscillatoriales Elenkin 1934). In: Garrity GM (ed) Bergey's manual of systematic bacteriology, 2nd edn. Springer, Berlin Heidelberg New York, p 539-562

Caudales R, Wells JM, Butterfield JE (2000) Cellular fatty acid composition of cyanobacteria assigned to subsection II, order Pleurocapsales. Int J Syst Evol Microbiol 50: 1029-1034

Cooney RP, Pantos O, Le Tissier MD, Barer MR, O'Donnell AG, Bythell JC (2002) Characterization of the bacterial consortium associated with black band disease in coral using molecular microbiological techniques. Environ Microbiol 4:401-413

Dinsdale EA (2002) Abundance of black-band disease on corals from one location on the Great Barrier Reef: a comparison with abundance in the Caribbean region. Proc 9th Int Coral Reef Symp 2:1239-1243

> Felsenstein J (1985) Confidence-limits on phylogenies: an approach using the bootstrap. Evolution 39:783-791

Francis JF (2001) Colorants. In: Watson DH (ed) Food chemical safety. Woodhead Publishing, Cambridge, p 173-206

Frias-Lopez J, Bonheyo GT, Jin Q, Fouke BW (2003) Cyanobacteria associated with coral black band disease in Caribbean and Indo-Pacific reefs. Appl Environ Microbiol 69:2409-2413

Frias-Lopez J, Klaus JS, Bonheyo GT, Fouke BW (2004) Bacterial community associated with black band disease in corals. Appl Environ Microbiol 70:5955-5962

Harel M, Ben-Dov E, Rasoulouniriana D, Siboni N and others (2008) A new Thraustochytrid, strain Fng1, isolated from the surface mucus of the hermatypic coral Fungia granulosa. FEMS Microbiol Ecol 64:378-387

Hoppert M, Holzenburg A (1998) Electron microscopy in microbiology. Bios Scientific Publications, Oxford

Kumar S, Tamura K, Nei M (2004) MEGA3: integrated software for molecular evolutionary genetics analysis and sequence alignment. Brief Bioinform 5:150-163

Mez K, Beattie KA, Codd GA, Hanselmann K, Hauser B, Naegeli H, Preising HR (1997) Identification of a micro- cystin in benthic cyanobacteria linked to cattle deaths on alpine pastures in Switzerland. Eur J Phycol 32: 111-117

> Myers JL, Sekar R, Richardson LL (2007) Molecular detection and ecological significance of the cyanobacterial genera Geitlerinema and Leptolyngbya in black band disease of corals. Appl Environ Microbiol 73:5173-5182

> Nübel U, Garcia-Pichel F, Muyzer G (1997) PCR primers to amplify 16S rRNA genes from cyanobacteria. Appl Environ Microbiol 63:3327-3332

Richardson LL (1998) Coral diseases: What is really known? Trends Ecol Evol 13:438-443

Richardson LL (2004) Black band disease. In: Rosenberg E, Loya Y (eds) Coral health and disease. Springer, Heidelberg, p 325-349

Richardson LL, Ragoonath DN (2008) Organic carbon enhances dark survival of the cyanobacterium Geitlerinema sp. isolated from black band disease of corals. Rev Biol Trop 56:119-126

> Richardson LL, Sekar R, Myers J, Gantar M and others (2007) The presence of the cyanobacterial toxin microcystin in black band disease of corals. FEMS Microbiol Lett 272:182-187

Rützler K, Santavy D (1983) The black band disease of Atlantic reef corals. I. Description of the cyanophyte pathogen. PSZN I: Mar Ecol 4:301-319

Saitou N, Nei M (1987) The neighbor-joining method: a new method for constructing phylogenetic trees. Mol Biol Evol 4:406-425

Sekar R, Mills DK, Remily ER, Voss JD, Richardson LL (2006) Microbial communities in the surface mucopolysaccharide layer and the black band microbial mat of black banddiseased Siderastrea siderea. Appl Environ Microbiol 72:5963-5973

Smith PT (1996) Toxic effects of blooms of marine species of Oscillatoriales on farmed prawns (Penaeus monodon, Penaeus japonicus) and brine shrimp (Artemia salina). Toxicon 34:857-869

> Sussman M, Bourne DG, Willis BL (2006) A single cyanobacterial ribotype is associated with both red and black bands on diseased corals from Palau. Dis Aquat Org 69:111-118

Talling JF (1969) General outline of spectrophotometric methods. In: Vollenweider RA (ed) A manual on methods for measuring primary production in aquatic environments. Blackwell Scientific, London, p 23

Taylor D (1983) The black band disease of Atlantic reef corals. II. Isolation, cultivation, and growth of Phormidium corallyticum. PSZN I: Mar Ecol 4:321-328

Van den Hoek C, Mann DG, Jahns HM (eds) (1995) Structure and characteristics of the Cyanophyta. In: Algae: an introduction to phycology. Cambridge University Press, Cambridge, p 24-32

Weil E (2004) Coral reef diseases in the wider Caribbean: status and prognosis. In: Rosenberg E, Loya Y (eds) Coral health and disease. Springer, New York, p 35-68

Willis B, Page CA, Dinsdale EA (2004) Coral disease on the Great Barrier Reef. In: Rosenberg E, Loya Y (eds) Coral health and disease. Springer, Heidelberg, p 69-103

Wilson K (1987) Preparation of genomic DNA from bacteria. In: Ausubel FM, Brent R, Kingston RE, Moore DD, Seidman JG, Smith JA, Struhl K (eds) Current protocols in molecular biology. Green Publishing, Wiley-Interscience, New York, p 2.4.1-2.4.5

Zvuloni A, Artzy-Randrup Y, Stone L, Kramarsky-Winter E, Barkan R, Loya Y (2009) Spatio-temporal transmission patterns of black-band disease in a coral community. PLoS One 4:e4993 